\title{
Emanuela Tenca*
}

\author{
Department of Economics and Management \\ University of Padua, Italy \\ emanuela.tenca@unipd.it
}

\section{REMEDIATING CORPORATE COMMUNICATION \\ THROUGH THE WEB: THE CASE OF ABOUT US SECTIONS IN COMPANIES' GLOBAL WEBSITES}

\section{Abstract}

International corporate communication has been impacted by the introduction of the Web, and organisations have an array of semiotic resources at their disposal to promote themselves worldwide. This paper aims at investigating the communicative choices supporting corporate image in the About Us/Company sections included in the global websites of 30 European companies active in the renewable energy sector. Hence, an analytical framework combining a genre and a corpus perspective has been devised with a view to focusing on form-function correlations as expressed by hyperlinks, visuals, and recurring lexico-grammatical patterns. Genre Analysis is instrumental in locating possible instances of text typologies belonging to corporate communication such as mission statements, company brochures, and CSR reports, while Corpus Linguistics offers ways of looking at linguistic choices. These frameworks have been integrated with Multimodal Discourse Analysis so as to examine hypertextual and multimodal features as well. The results show that About Us/Company sections are now loci for the projection of a favourable corporate image, and that companies are well aware of the importance of delivering their message by balancing textual, hypertextual, and multimodal strategies. Some pedagogical implications for the ESP classroom are also discussed in the paper.

\section{Key words}

companies' websites, corporate communication, corporate identity, mission statements, company brochures, corporate social responsibility.

\footnotetext{
* Corresponding address: Emanuela Tenca, Department of Economics and Management, University of Padua, Via U. Bassi 135131 Padua, Italy.
} 


\section{Sažetak}

$\mathrm{Na}$ međunarodnu korporativnu komunikaciju uticala je pojava interneta i organizacije sada imaju čitav niz semiotičkih sredstava na raspologanju kako bi se promovisale širom sveta. Cilj ovog rada je da istraži načine komunikacije putem kojih se gradi korporativni imidž u odeljku 0 nama/Kompanija na globalnim veb sajtovima 30 evropskih kompanija koje posluju u sektoru obnovljivih izvora energije. U tu svrhu, osmišljen je analitički okvir koji kombinuje žanrovsko i korpusno istraživanje s ciljem da se otkriju korelacije između oblika i funkcije izražene putem hiperlinkova, vizuelnih sredstava i najčešćih leksičko-gramatičkih obrazaca. Analiza žanra je od pomoći pri otkrivanju mogućih primera tipova teksta u domenu korporativne komunikacije, kao što su misija kompanije, kompanijske brošure i izveštaji o korporativnoj društvenoj odgovornosti, dok korpusna lingvistika omogućava istraživanje jezičkih sredstava. Ova dva okvira integrisana su sa multimodalnom analizom diskursa kako bi se istražila i hipertekstualna i multimodalna svojstva. Rezultati pokazuju da odeljak 0 nama/Kompanija danas predstavlja mesto za projektovanje povoljnog korporativnog imidža, kao i da su kompanije svesne značaja načina slanja poruke kojim se jednako koriste tekstualne, hipertekstualne i multimodalne strategije. U radu predočavamo i neke pedagoške implikacije za nastavu engleskog jezika nauke i struke.

Ključne reči

veb sajtovi kompanija, korporativna komunikacija, korporativni identitet, misija kompanije, kompanijske brošure, korporativna društvena odgovornost.

\section{INTRODUCTION}

Corporate communication is "the process through which stakeholders perceive the company's identity and image and reputation are formed" (Balmer \& Gray, 1999: 171). It comprises many practices, as for instance exchanges between managers and the company's internal and external stakeholders, activities promoting brands and supporting sales (i.e. advertising), as well as those messages targeted towards shareholders, journalists, analysts, and legislators, which aim at providing the company's institutional presentation (Melewar \& Karaosmanoglu, 2006; Poppi, 2012; Van Riel \& Fombrun, 2007).

Every activity taking place in a company affects stakeholders' opinions (Van Riel \& Fombrun, 2007). Thus, it is crucial for successful corporate communication that its several practices be integrated in a coherent and total system, although this 
task is difficult to accomplish given its implied complexities (Christensen, Fuat Firat, \& Cornelissen, 2009).

Nowadays, competition has become even fiercer than in the past, and companies' accountability has gained high priority. In this context, international corporations avail themselves of the Web medium to meet the challenges of globalised business, and they have adopted English as a shared code to trade worldwide. Following from these premises, a problematisation of corporate communication is demanded to understand how organisations currently manifest their identity and maintain reliability in their stakeholders' eyes.

In particular, a remediation (Bolter, 2001, 2016; Bolter \& Grusin, 1999; Heyd, 2016) from printed documents to web-mediated hypertexts has been brought about in the last decades, and companies' websites are now a sine qua non of corporate communication. These function as large repositories of the informative and promotional contents which were once available only in hard copy. Some of the texts in companies' websites are specifically designed to offer an institutional profile of the company, and they are included in the so-called About Us or Company section (Breeze, 2013; Esrock \& Leichty, 2000; Perry \& Bodkin, 2002; Pollach, 2005; Turnbull, 2011, 2013). Texts in companies' websites are combined via hyperlinks, and they can be accessed online by anyone, anywhere in the world, and at any time. These texts also rely on both written information and other semiotic resources such as visuals, colour scheme, and document layout, and in this sense they have been resemiotised (Iedema, 2003; 0'Halloran, 2011). Besides, in order to extend the participation framework to a global audience, an English version of the website is usually published, which caters for the needs of international stakeholders.

In sum, the discursive choices subsuming international corporate communication have been refashioned and adapted to the web-mediated environment. This raises an important question: what are the ways in which textual information cooperates with hyperlinks and with other semiotic resources in order to shape companies' identity and project their positive image?

This research question is addressed by drawing from the principles of genre theory, thus following other genre-based studies of companies' websites conducted in the last two decades, such as Askehave and Ellerup Nielsen (2005), Catenaccio (2012), Ellerup Nielsen (2002), Garzone (2007), and Turnbull (2011, 2013). Indeed, the concept of genre allows us "to gain a better understanding not only of the linguistic characteristics of texts, but also of their macro-structure, which appears to be organised according to genre expectations and conventions rooted in the socio-cultural context" (Gotti, Berkenkotter, \& Bhatia, 2012: 10). In particular, this study relies on the approach framed by Swales (1990) and Bhatia (1993, 1996, 2004) in the field of English for Specific Purposes (ESP), since this emphasises the dynamic nature of professional genres: their flexibility affords an adaptation to new conditions in the communicative contexts, such as those depending on technological advances and increasing competitiveness (Bhatia, 
1996). Accordingly, the Web medium and its capabilities, together with the present-day globalised business scenario, are considered crucial factors in today's international corporate communication.

In order to appropriately consider the communicative potential of the medium in shaping and spreading companies' message, the framework of ESP is integrated with Multimodal Discourse Analysis (Bhatia, Flowerdew, \& Jones, 2008; Iedema, 2003; Jewitt, 2014, 2016; Lemke, 1998; O'Halloran, 2004, 2011), which is based on the assumption that concepts of linguistic investigation can be extended to other semiotic modes, in order to explore how language, hyperlinks, and visuals equally contribute to the meaning-making process.

In what follows I will introduce three well established textual realisations of corporate communication, i.e. mission statements, company brochures, and CSR reports. Secondly, I will survey case studies illustrating the main characteristics of companies' websites. Next, I will present the objectives, materials, and methods applied in this research and discuss the findings of my analysis. Finally, I will draw conclusions about the approach taken by companies to carry out their corporate communication. Limitations of the study, paths for future research, and implications for the ESP classroom are accounted for as well.

\section{MISSION STATEMENTS, COMPANY BROCHURES, AND CSR REPORTS}

Corporate communication is characterised by professional genres which well exemplify text production within the business domain, and which are designed to verbalise companies' positive identity and shape stakeholders' favourable perception of their image. For instance, mission statements are the textual instantiation of the vision, mission, and aims which companies need to develop and announce to support their reputation (King, Case, \& Premo, 2010; Topalian, 2003). In general, mission statements are addressed to both internal and external stakeholders: the former rely on these texts to establish whether their modus operandi is in line with the organisation's philosophy, while the latter allow them to get insights into the company's objectives (King et al., 2010). From a textual perspective, mission statements might be labelled in a variety of ways, as for instance Our Mission, Our Commitment, or Vision, and they consist of "general statements, claims and conclusions" (Swales \& Rogers, 1995: 226-227) about a company's practices. They are usually written by senior executives or by CEOs, and their contents might vary, although they "tend to stress values, positive behavior and guiding principles within the framework of the corporation's announced belief system and ideology" (Swales \& Rogers, 1995: 227). The traditional printed version of mission statements usually consists of textual information, while other semiotic modes, as for instance visuals, are almost absent (Swales \& Rogers, 1995). 
As for company brochures, these are polysemiotic texts (Nielsen, 2001) whose focus is on the message-sender (i.e. the company), and which are used by organisations to present themselves as qualified partners (Askehave, 1998). The companies' professional identity is substantiated by the use of technical terminology belonging to their industry sector (Bhatia \& Lung, 2006; Cheng, 2011). Company brochures have been conceptualised as peripheral members of the colony of promotional genres by Bhatia (2004): their primary function is informative, but they also fulfil a secondary promotional function, which they share with other primary members of the colony (e.g. advertisements and sales promotion letters). Indeed, the language of company brochures is partly descriptive, in that facts and figures about the message-sender are presented, and partly evaluative, in that the company's positive image is projected.

Concerning CSR reports, the construct which underpins these textual realisations has been much debated, and several definitions have been offered. One way to frame Corporate Social Responsibility has been propounded by Dahlsrud (2008), who has pinpointed five dimensions of CSR, i.e. the economic, the social, the environmental, the voluntariness, and the stakeholder dimension. The economic, the social, and the environmental dimensions account for the "different categories of impacts from business", and they imply "that business, as a producer of economic wealth, does not only have economic impacts" (Dahlsrud, 2008: 6), while the voluntariness dimension indicates "that the business should perform above regulatory requirements, which will set the minimum performance level deemed acceptable" (Dahlsrud, 2008: 6). The voluntariness dimension is closely related to the stakeholder dimension, which establishes the optimal business performance level. CSR reports belong to the colony of reporting genres (Bhatia, 2004), and companies generally refer to them by using phrases such as Corporate Citizenship and Sustainable Development (Tang, Gallagher, \& Bie, 2015). However, in recent years the majority of European for-profit organisations have opted for Sustainability as their label of choice (Gatti \& Seele, 2014; Lock \& Seele, 2016). In addition, from a textual perspective CSR reports are recursive, in the sense that they exhibit the same structure chapter by chapter (Yu \& Bondi, 2017).

In short, the three genres reviewed in this section express the strategies deployed by companies to construct and promote their corporate identity. The advent of the Web has led to a transition from printed to digitised texts, which needs to be critically approached in order to pin down the discursive features of present-day international corporate communication.

\section{WEB-MEDIATED CORPORATE COMMUNICATION VIA COMPANIES' WEBSITES}

One of the first attempts at classifying companies' websites was made by Kotler (1998), who introduced a terminological distinction between corporate and 
marketing websites. The former are "designed to answer customer queries, build customer relationships and generate excitement about the company rather than to sell the company's products or services directly", whereas the latter are employed to "interact with the consumers for the purpose of moving them closer to purchase or other marketing outcome" (Kotler, 1998: 971).

Ellerup Nielsen (2002) draws from this typology to analyse companies' websites from a discursive perspective, but she rightly observes that, as a result of the continuous changes brought about in the domain of communication technologies, these two categories have combined and united into one artefact displaying the formal features and communicative functions of both. Therefore, the author sets out "to examine to which extent the traditional rhetorical features of printed material are transformed when digitalised" (Ellerup Nielsen, 2002: 11). First of all, her investigation concentrates on the hypertextual nature of companies' websites. As a hypertext (Bolter, 2001; Landow, 2006), a website has a unifying function, since it gathers all the information related to a company in one online locus. However, the fact that information is divided and condensed into several units connected by hyperlinks places some constraints on the way in which websites are eventually accessed, in the sense that reading conditions on the Web are "characterized by high speed and fragmentation" (Ellerup Nielsen, 2002: 12).

Following from the assumption that the contents traditionally conveyed in hard copy by means of company brochures have migrated to companies' websites, Ellerup Nielsen (2002) demonstrates that meaning is co-constructed by different semiotic modes. As for language use, several differences exist between company brochures and websites. In fact, the language employed in the former is evaluative, persuasive, and emotional, whereas the language employed in the latter is more concise and informative. Furthermore, company brochures display instances of meta-communicative phrases to guide the user in accessing the information. In contrast, websites' texts do not present any explicit meta-communicative pattern, and the argumentation is based on cause-effect relationships. The reason Ellerup Nielsen (2002) offers to explain these differences lies in the hypertextual property of web-mediated documents, which navigators access in a non-linear way, and which they usually scan rather than read sequentially.

Therefore, information on websites is denser than on printed texts as a consequence of the adaptation process that companies' promotional material undergoes when it is transferred to the Web. To this concern, Ellerup Nielsen (2002) expresses a word of caution by observing that the higher incidence of factual information might run counter to the persuasive function of this type of material issued by companies.

A further contribution tackling companies' websites is offered by Bolaños Medina, Rodríguez Medina, Bolaños Medina, and Losada García (2005). The characterisation they propose attests to the inherent hybridity of websites, which in turn is a function of their hypertextuality. As the authors put it, companies' 
websites are made up of several information units, "1 "some of which constitute different digital genres on their own and whose limits are fuzzy" (Bolaños Medina et al., 2005: 126). In their investigation, Bolaños Medina et al. (2005) map the structural features of websites following three sets of parameters, i.e. images, linguistic markers, and functionality, as expressed by internal and external hyperlinks, along with other capabilities of the Web which allow to order products online, or ask for customer support. They recognise the coexistence of several semiotic modes, and especially the relevance of visuals used to promote the companies' products. As for linguistic markers, the use of the imperative and of the present simple, together with the high incidence of the modal "can", the plural pronouns "we" and "us", the active voice, and the presence of evaluative adjectives in pre-modifying position, are in keeping with "the vocative and descriptive nature of the content of these websites" (Bolaños Medina et al., 2005: 143). With regard to functionality, the authors observe that internal links are used more frequently than external links. Internal links are especially conceived for customers to place online orders, or ask for support.

The studies described above provide interesting insights into web-mediated corporate communication by exploring rhetorical features along with the presence of visual items and the use of hyperlinks. This knowledge is adopted as a starting point to conduct research in the domain of web-mediated corporate communication.

\section{OBJECTIVES, MATERIALS, AND METHODS}

This research is based on the fact that companies' websites are a major component of present-day corporate communication. Within companies' websites, About Us/Company sections play a fundamental role, since they are dedicated to disclosing the message-sender's institutional profile (Breeze, 2013; Esrock \& Leichty, 2000; Perry \& Bodkin, 2002; Pollach, 2005; Turnbull, 2011, 2013), and so they provide information about an organisation while projecting its positive image as a reliable business partner. The aim of this research is to examine the discursive and multimodal strategies which underlie today's web-mediated corporate communication in the texts included in these sections.

In order to pursue this objective, the present investigation delves into the About Us/Company sections in the global websites of 30 European companies operating in the renewable energy sector. The analysis also endeavours to locate digitised versions of mission statements, company brochures, and CSR reports, while also identifying possible instances of variation on the basis of previous research by Ellerup Nielsen (2002) and Bolaños Medina et al. (2005).

\footnotetext{
${ }^{1}$ The authors employ the term 'nodes' to designate the information units which form a hypertext. This term is also used by Ellerup Nielsen (2002) and Landow (2006).
} 
The small-scale corpus employed for the present analysis, totalling 68,098 word tokens and 7,510 word types, was collected between November and December 2014 and was built by applying two criteria. Firstly, I have singled out companies dealing with renewable energy on account of the high stakes of this industry sector, which plays a key role for global health, environmental protection, and economic growth. Secondly, I have chosen companies headquartered in countries where English is not a native language, with a view to exploring how international organisations adopt and adapt English for the purposes of international corporate communication. An overview of the websites collected, indicating the companies' name, their country of origin, and the URL of the websites is provided in the Appendix.

The homepages of the websites represent the point of departure in the present investigation, since they feature hyperlinks leading to the About Us/Company sections. These sections are then examined by using Bolaños Medina et al.'s (2005) framework: the structural features of the About Us/Company sections to be analysed are hyperlinks, visuals, and linguistic markers.

The first element which is accounted for are hyperlinks, as these illustrate how the About Us/Company sections can be accessed from the homepages, and how they are internally organised. Secondly, logos and banners are mapped. These elements are important, since logos are visual items symbolising the companies' identity (Van Riel \& Fombrun, 2007: 11), while banners are used not only as a framing device, but also to present companies' message (Bolaños Medina et al., 2005: 129). The position of visuals within the web page layout is also considered, as it attests to their information value. To this effect, Kress and Van Leeuwen's (2006) categorisation of composition will be adopted. According to them, elements on the right of a composition represent given information, while elements on the left represent new information. Next, elements at the top of a composition represent the ideal dimension of the message, while elements at the bottom represent its real dimension. Finally, elements arranged in the margins of a composition are subservient to the elements placed in the centre.

The analysis of linguistic markers has been conducted by processing the About Us/Company sections in the AntConc concordancing tool (Anthony, 2012). In this way, I have created a frequency word list and generated concordances which help disclose the most frequently occurring grammatical and lexical items referring to the message-senders. These markers have been singled out on the assumption that they occur in lexico-grammatical patterns aiming at projecting the companies' image.

\section{FINDINGS}

In this section, I will group the results of my analysis into three categories. Firstly, I will look at those hyperlinks on the companies' homepages which lead to the 
About US/Company sections, and I will consider how they are realised to support the internal organisation of the sections. Secondly, I will focus on visual elements and on their information value within the overall composition of the web pages. Finally, I will account for the communicative strategies implemented in the sections by examining form-function correlations as expressed by frequent linguistic patterns.

\subsection{Hyperlinks}

The results show that the homepages of 27 websites contain at least one hyperlink leading to the companies' institutional profile. In particular, 11 organisations refer to their institutional profile with a prepositional phrase introduced by "about", i.e. "About Us", "About", and "About" followed by the company name; 11 have adopted a noun phrase including the nouns "company" or "group", while 5 have included their name in the hyperlink.

Some hyperlinks deserve further attention. For instance, when the hyperlink includes the organisation's name, the noun "Group" might follow, as in the case of organisations controlling other companies. One of the homepages is worth noticing because it directs users to two sections dedicated to the corporation's profile: one is introduced by the hyperlink "About", the other by the hyperlink "Group". The former section provides a general presentation of the corporation, while the latter is dedicated to its subsidiaries. Three homepages do not appear to have any link leading to the company's profile. Nonetheless, a closer investigation of these websites reveals that they are provided with an institutional presentation. In one case, it can be accessed by clicking on two generic links, "Home" and "Asset Manager"; in another case, it is included in the main text in the middle of the homepage; finally, one company's profile can be accessed by clicking on a large banner spanning the width of the screen.

As regards the internal organisation of the About Us/Company sections, it emerges that, once the section is accessed, a graphic control element appears on the page. Its function is comparable to that of a table of contents, and therefore it will be referred to as such in the remainder of this paper. This element might be static or dynamic. In the former case, it is organised either vertically or horizontally, while in the latter it is realised by means of a drop-down menu. When the institutional self-presentation occupies one web page, no table of contents is provided.

Static, vertically oriented tables of contents present the links as stacked one on top of the other, and they are showcased on the left-hand side of the screen. Nine companies have opted for this graphic control element. Further two companies feature a vertical table of contents, but it is positioned on the right-hand side of the page, whereas five companies present a static, horizontally oriented table of contents. 
Eight companies feature a dynamic table of contents realised as a drop-down menu. Among these, one website stands out for two reasons. First of all, the menu does not drop down, but it opens upward once the navigators point the mouse cursor on the navigation bar. Secondly, the web pages in the About Us/Company section are provided with an additional static table of contents, which is placed on the lower left-hand side of the screen, as exhibited in Figure 1.

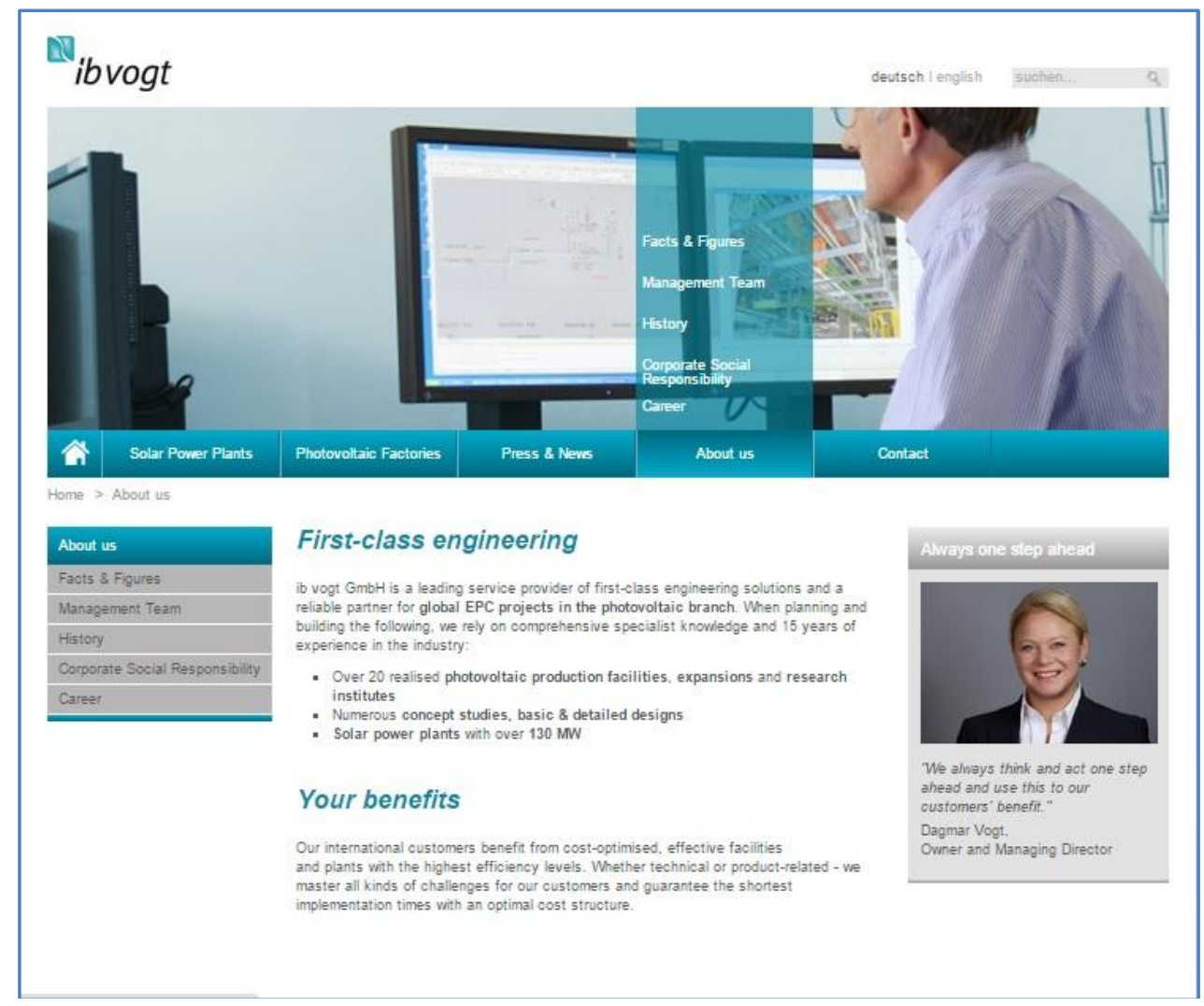

Figure 1. Dynamic and static tables of contents in ib vogt GmbH's About Us section

Overall, the links included in the tables of contents can be conceptualised as functional units: the links offer an overview of the contents of the section, while also giving access to it. Besides, they provide guidance in retrieving possible texts of corporate communication. In particular, 13 organisations have uploaded their mission statement. The hyperlinks to mission statements are phrased in different ways, and in some cases the related texts are on more than one web page.

Interestingly, a closer look at the websites reveals that one company has uploaded its mission statement as a single-page section which can be directly accessed from the homepage (Figure 2). 


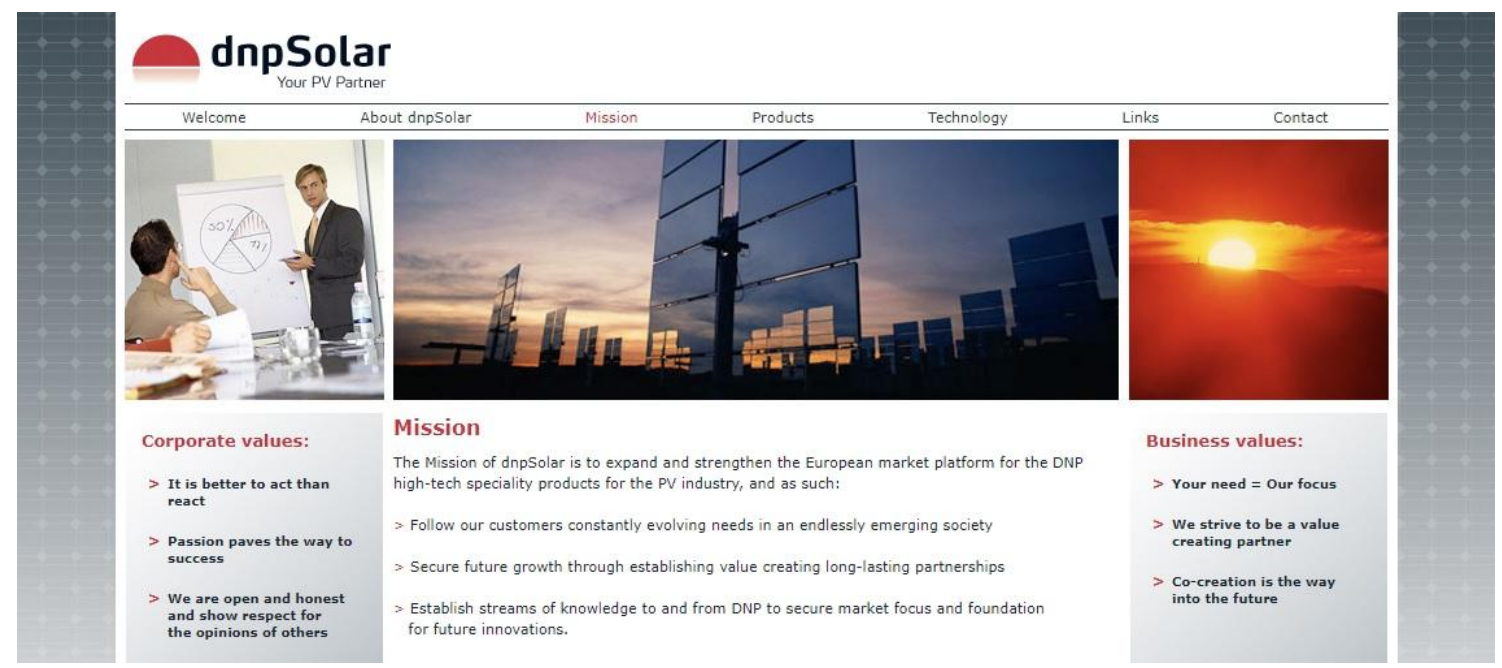

Figure 2. dnpSolars' mission statement

As for CSR, this can be found in the About Us/Company sections of three organisations. The texts are titled "Social responsibility" by two companies and "Corporate social responsibility" by one, and they lie on a single web page. Nonetheless, similarly to the mission statement in Figure 2, there are three further companies which have uploaded CSR information to dedicated sections linked directly to their homepages. These sections are titled "CSR", "Sustainability", and "Responsibility". One of these companies organises its CSR on two web pages, one on six pages, while one organisation articulates its message in five sub-sections which in turn comprise multiple pages. ${ }^{2}$

Overall, the analysis conducted has revealed that, at the level of hyperlinks, About Us/Company sections are designed in a standardised way which is in line with the findings of previous research (Breeze, 2013; Esrock \& Leichty, 2000; Perry \& Bodkin, 2002; Pollach, 2005; Turnbull, 2011, 2013). The common features emerging from the corpus indicate that in general organisations abide by shared norms of web design to meet the expectations of their users, and thus provide them with guidance while they navigate their institutional profile.

One interesting result is the limited presence of traditional texts of corporate communication. Although it is not possible to make generalisations given the small number of companies researched, it seems that at present there are no strict conventions regarding the contents which should be included in About Us/Company sections. This lack of conventions gives companies the freedom to experiment with the properties of the medium and hence get their message across in personalised ways.

\footnotetext{
2 Company brochures have been retrieved from the About Us/Company sections of three organisations, but they have not been accounted for in this study because they are realised as pdf files. In fact, pdf files are not to be categorised as hypertexts, since they are designed to be downloaded and printed out (Garzone, 2009).
} 


\subsection{Visuals}

The images in the About Us/Company sections exhibit some regularities. In general, the top section of the web pages includes the companies' logos. Logos, which project the companies' visual identity, are reiterated on all the web pages within the institutional profile. This provides visual cohesion and coherence across the sections. Logos are always positioned at the top of the web pages, thus representing the ideal dimension of the message conveyed by the company. Moreover, they are usually placed in the top left-hand side corner of the screen (Figure 1 and 2), except for the web pages in the About Us/Company sections of three organisations. In two of these, the logo lies in the middle of the upper section, while in one it lies in the top right-hand side corner.

Further frequent visual elements on the web pages explored are banners. Nineteen companies in the corpus include a banner on the web pages in their institutional profile. The banners are all positioned in the upper section of the web pages, thus partaking of the ideal dimension of the composition. Additionally, banners function as framing devices by subdividing the web pages into two sections. The upper sections include the companies' logo, the table of contents, and the banner itself, while the lower sections might include a block of text and further images. The composition of web pages including a banner is represented in Figure 3.

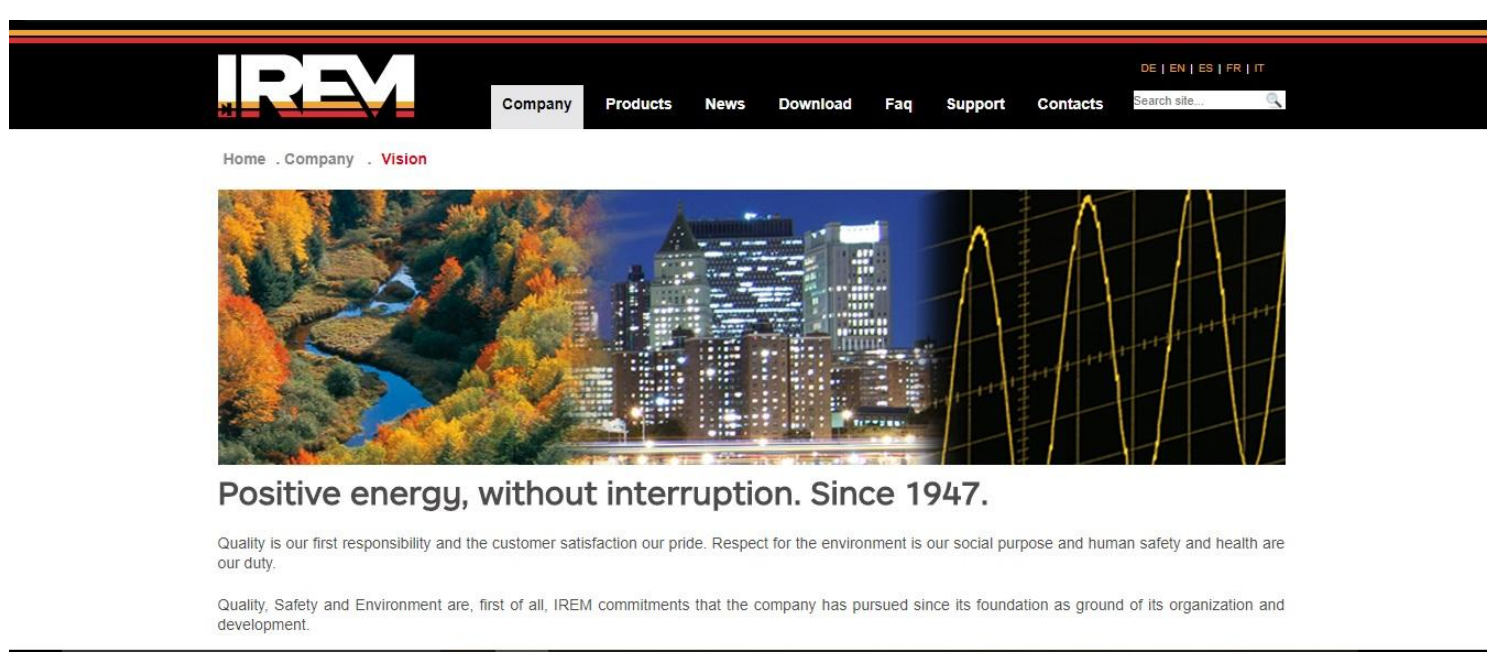

Figure 3. IREM SpA's mission statement

The findings of the visual analysis presented above are consistent across the small-scale corpus, and they are congruent with Bolaños Medina et al.'s (2005) results. For instance, images are structural features carrying out a number of purposes. Logos establish the message-sender's credentials while also contributing to the cohesion and coherence of the website, as they are positioned on all the web 
pages in the About Us/Company sections. Banners function as framing elements, but their prominent position is also essential in attracting navigators' attention and convincing them to stay on the website. This is crucial, considering that webmediated texts are processed in a rapid and fragmented way.

In addition, images incorporated into mission statements confirm that traditional genres of corporate communication have been resemiotised when migrating to the Web. The occasional presence of audio-visual contents strengthens this idea by revealing the potential of the medium: on the Web, stakeholders can be engaged in the corporate communication on several semiotic planes, and if organisations are able to skilfully exploit the many resources offered by the medium, they can secure a wide online audience for their website.

\subsection{Linguistic markers}

By using the AntConc concordancing tool, it was established that "our" ranks 9th among the 20 most frequent words in the corpus with 657 occurrences, whereas "we" ranks 10th with 626 occurrences. The most frequent lexical item, "company", ranks 18th with 337 occurrences. In order to illustrate the most effectively employed linguistic choices projecting the companies' positive image, concordance lines have been generated by searching "we" and "company" as node words, on the assumption that these appear in contexts where the companies present themselves. The use of the possessive "our" has also been considered, as it is often to be found in the co-text of "we".

\subsection{1. "We"/“our"}

The analysis has revealed that "we" is usually employed as a receiver-excluding pronoun to refer to the message-sender (the company). While the use of the third singular pronoun usually makes communication between message-sender and message-receivers (in this case, companies' stakeholders) indirect and formal, the first person plural pronoun personifies the message-sender and makes communication more captivating and emotional. This is apparent in the following examples.

(1) We keep our Vision, Mission and Initial Values aiming to be the best in the market that we work, with a strong sense of responsibility in society [...]. (A. Silva Matos Energia SA)

(2) As all our products are custom-made we will give full customer support with our own R\&D, Engineering, Logistics and Quality departments. (JL MAG Rare-Earth Co. Europe b.v.) 
(3) We consider that our people are the most valuable assets of our company. (Silcio SA)

As the examples show, the co-text surrounding the pronoun "we" verbalises the values, vision, and mission of the organisations, as well as their commitments to external and internal stakeholders. The content of the propositions expresses the company's positive principles by using the present simple. This is a common rhetorical feature of mission statements (Swales \& Rogers, 1995: 227). In (1), the phrase "a strong sense of responsibility" denotes the company's attitude towards a fundamental stakeholder group, society. In (2), implicit reference is made to customers by means of the compounds "custom-made" and "customer support". The company seeks to make a good impression on these stakeholders by also indicating its "R\&D, Engineering, Logistics and Quality departments". In (3), the phrase "our people" thematises the identity of employees as a group of individuals rather than workers, while the phrase "the most valuable assets" shows that the company explicitly acknowledges their role, with a view to building consensus among them.

The recurring use of personal self-reference exemplified by the excerpts above is typical of genres within corporate discourse, e.g. annual reports (Breeze, 2013), and it indexes the dialogic nature of these texts, as it is employed to foster solidarity between the companies and their stakeholders (Breeze, 2013). The persuasive function of "we" is corroborated by the presence of words and phrases with positive evaluative meaning, which add to the companies' favourable image. In this sense, "responsibility" is a keyword in (1), as it reinforces the organisation's legitimate role not only in the market in which it operates but also in society at large. Indeed, it shows its commitment to the environmental cause by relying on the fact that it deals with renewable energy sources.

\subsection{2. “Company"}

This noun is used across the whole corpus to disseminate information about the company's history, location, turnover, etc. Language is descriptive, the third person singular is used, and the reference to the message-sender is indirect.

(4) The company has a turnover of around $€ 200$ million, $90 \%$ of which are exports. (Cryostar SAS)

(5) The company now has over 30 years of industry experience and is still family owned. (Deep Drill Supply Group)

(6) Mervento Oy is a Finnish company owned by the founders Martti Ala-Vainio and Patrik Holm and the investors Power Fund II, which is managed by VNT Management Oy, Soldino Oy, Mutual Pension Insurance Company Varma, AC Cleantech Growth Fund I Holding AB, EPV Energia Oy and company's own personnel. (Mervento Oy) 
In (4), the numerical data provided to describe the company's turnover and exports are instances of factual information with a covert persuasive function: by disseminating these data, companies aim at promoting themselves as reliable partners. However, the information about the company's turnover is vague, as it is mitigated by the preposition "around". A similar strategy is implemented in (5), where the phrase "over 30 years" is employed to describe the company's experience. In (6), the full names of the company's owners, founders, and investors are disclosed: by overtly stating the names of people and organisations responsible for the company's management, the message-sender delivers a transparent message, while at the same time projecting its image as a trustworthy business partner.

From the examples commented above, it emerges that the companies' identity is built around factual information such as their turnover, history, founders, management, and ownership. The effect of deploying this rhetorical strategy is different from the one obtained using the receiver-excluding pronoun "we": the organisations describe themselves in objective terms, and the image which is projected is authoritative. However, it can be hypothesised that the third person singular rather than the pronoun "we" is used in (4) to avoid sounding intimidating (Cheng, 2011), since numerical data about the company's performance are disclosed.

Finally, a word of caution is needed regarding the presence of numerical information. The figure provided in (4) is approximate, and it makes the message less transparent than it might seem at first. The effectiveness of this strategy in the eyes of the target audiences might be questioned. Nonetheless, this vagueness allows for open interpretation and versatility on the part of the message-senders (Breeze, 2013), as it accounts for any fluctuation in the amount of business done by the company over a certain period of time.

\section{DISCUSSION}

The analysis has shown that corporate communication via companies' global websites takes place on several levels and that it lies in a grey area between standardisation and variation: indeed, the potential of the communication tools afforded by the medium allows companies to design their online institutional profiles in personalised ways. As for standardisation, the hyperlinks on the homepages are instrumental in directing users to the About Us/Company sections. The organisations employ similar linguistic patterns to realise them, and this seems to confirm that institutional profiles are well-established components of web-mediated corporate communication.

In contrast, some variation has been noticed in the internal design of the sections, although guidance to navigators is generally offered by a graphic control element here referred to as table of contents. This also indicates whether any 
traditional texts of corporate communication have been uploaded. Surprisingly, less than half of the About Us/Company sections analysed feature a hypertextual mission statement, and only three include contents directly referred to as CSR. Company brochures have been mapped, but these are pdf files lacking the hypertextual property of websites. Furthermore, it has been noticed that some organisations disseminate information about their mission and CSR by devising dedicated sections directly accessible from the homepage.

The few instances of mission statements and CSR reports retrieved do not allow for generalisation, also considering the limited size of the corpus used. However, even if these genres are underrepresented in the websites analysed, we could argue that they have been remediated and resemiotised, to the extent that they can be navigated thanks to hyperlinks, and they convey the companies' message by integrating textual and visual items. In particular, the presence of multimodal elements on web-mediated mission statements represents the most relevant difference vis-à-vis traditional printed mission statements.

Moreover, the linguistic and multimodal analysis has revealed how the About Us/Company sections fulfil the same partly informative and partly promotional function of traditional company brochures. The rhetorical choices aim at projecting the companies' positive image by balancing descriptive and positively connoted language, and they are complemented visually by logos and banners. In fact, logos are always present, and by being placed in the upper section of the web pages they foreground the companies' identity. Banners are recurring visual elements too, which go hand in hand with textual information by contributing to the implied promotional function of the institutional profiles. However, they also serve as framing devices.

In addition, the linguistic investigation has shown that the companies' mission, vision, and values are signposted by the personal pronoun "we". The promotional message is supported by positively connoted language in the co-text of the pronoun, and this is in contrast with Ellerup Nielsen's (2002) findings, which indicate the prevalence of factual over persuasive language in the websites she investigated.

Factual language is used too, and it is here contended that it fulfils a covert persuasive function: by disclosing facts and figures, the companies build their identity as reliable business partners. Finally, reference to the companies' stakeholders is made with a view to captivating their benevolence, and this strategy partakes of the overall promotional function of the section.

\section{PEDAGOGICAL IMPLICATIONS}

Following from the widely acknowledged importance of linking insights from linguistic research with the practice of teaching, I will consider some pedagogical implications which the results of the present study might have for the ESP 
classroom. Applications could be found in the teaching of Business English, which is here construed in line with Zhang (2007) as the range of communicative strategies implemented in the international business domain; in this domain, participants need to abide by certain professional conventions to function properly, and they should take on board not only the resources offered by the English language in both written and spoken forms, but also those catered for by other semiotic resources.

This definition of Business English is particularly relevant here, as it accounts for the role played by multimodality in spreading companies' message, as highlighted in the analysis conducted above. Moreover, we need to consider that reading very often takes place online, especially in the case of texts disseminated by companies. Therefore, ESP teaching practices should first of all build on "systematic technical knowledge of the ways semiotic resources are deployed in meaning making" (Archer, 2010: 211), in order to guide students in becoming aware of how information is processed in the hypertextual and multimodal Web environment. As Crawford Camiciottoli and Bonsignori point out, "a multimodal approach to teaching and learning can provide students with a new strategy to cope with the challenges of specialized language" (2015: 142).

To raise students' awareness of how meaning is encoded in companies' websites, Noguchi's (2003) "OCHA" approach could be adopted and adapted. The acronym, which stands for Observe, Classify, Hypothesise, and Apply, brings together the kinds of tasks students need to carry out to become familiar with the linguistic features of professional texts (Noguchi, 2003). By applying this approach to About Us/Company sections, students would be guided in first of all observing how information is hierarchically organised, how hyperlinks are used to guide navigators, and how blocks of texts and visual items are combined. Additionally, they could be asked to retrieve the various typologies of documents included in the sections. After having mapped textual, hypertextual, and multimodal contents, students would be asked to classify them into categories such as "texts", "hyperlinks", "images", and then to analyse the formal features of the elements in each category in order to make hypotheses regarding their communicative functions. At this stage, linguistic strategies could be examined by using tools of Corpus Linguistics: students could gather a small-scale corpus of texts and then use a concordancer to generate frequency lists and concordance lines. This quantitative approach could be complemented by a qualitative one, so that students would be given the possibility to focus on just one or few texts, and thus delve deeper into the interplay existing between the rhetorical choices characterising corporate communication on the one hand, and on multimodal strategies pursued in global websites on the other.

Finally, students could apply the insights thus gained to work on a project where they would have to plan the design of an About Us/ Company section. This should be a collaborative task, where students are divided into groups, and in each group one or two students are responsible for one component of the section they 
are to create. This activity implies a constant exchange of information among the students in a group, to make sure that the communicative choices made for individual components of the section are consistent with one another.

All in all, the tasks suggested above aim at confronting students with authentic multimodal hypertexts which in the future they might have to create as part of their professional activities, and with the challenges that these pose. Indeed, it is paramount that in today's ESP classroom the acquisition of textual and discursive competences is complemented with that of multimodal competences, in order to help novices become successful professional communicators.

\section{CONCLUSION}

In the present-day competitive business setting, it is crucial for internationally operating companies to appropriate all those tools which might serve the purposes of their corporate communication. This is even more relevant in high-stake sectors such as the renewable energy industry.

The analysis presented above has provided insights into the communicative strategies deployed by companies to shape their identity as trustworthy business partners, and to project their positive image in front of their international stakeholders, in the so-called About Us/Company section of companies' websites. The strategies which have been nailed down are consistently integrated to participate in the meaning-making process. The potential of hyperlinks and images is exploited to encode meaning, and thus fulfil the companies' communicative agenda.

In sum, the About Us/Company sections are constellations of multimodal texts which are to be classified under the rubric of corporate communication. As such, they can be regarded as the online version of traditional company brochures, but they have also remediated contents of other genres belonging to corporate communication, namely mission statements and CSR reports.

This research may help raise awareness in professionals employed in international for-profit organisations on how to successfully communicate with their international audiences in today's globalised and digitised business environment. Furthermore, it is meant to be relevant for the teaching of English for Specific Business Purposes, as it should encourage trainers of future managers to support novices in acquiring skills which are essential to efficiently handle the Web medium and the English language when entering the professional world. Nevertheless, this study is not meant to be either prescriptive or exhaustive, and some limitations need to be acknowledged regarding the size of the corpus, the choice of materials and the methodology applied. These limitations can in turn open up new avenues of research. Firstly, it is advisable to build a larger corpus to lend validity to the findings discussed above, or to find evidence of variation. Caution is to be expressed also with regard to the fact that my analysis is limited to 
About Us/Company sections only. The investigation of other sections in company's global websites could shed further light on the use of promotional discourse in corporate websites. For instance, an analysis of press archives could indicate how companies combine news discourse with institutional advertising. To conclude, effort should be put into complementing textual analysis with ethnographic research conducted via online surveys and interviews in order to gain insider knowledge, in line with Bhatia's (2004) shared vision of ESP and professional practice.

[Paper submitted 13 Aug 2017]

[Revised version received 8 Feb 2018]

[Revised version accepted for publication 2 Mar 2018]

\section{References}

Anthony, L. (2012). AntConc (Version 3.3.5w) [Computer Software]. Tokyo: Waseda University. Retrieved from http://www.laurenceanthony.net/

Archer, A. (2010). Multimodal texts in higher education and the implications for writing pedagogy. English in Education, 44(3), 201-213. doi: 10.1111/j.1754 8845.2010.01073.x

Askehave, I. (1998). A functional interpretation of company brochures: From context to text. Summary of PhD thesis. Hermes, 21, 199-203. doi: 10.7146/hjlcb.v11i21.25485.

Askehave, I., \& Ellerup Nielsen, A. (2005). Digital genres: A challenge to traditional genre theory. Information Technology \& People, 18(2), 120-141. doi: 10.1108/09593840510601504

Balmer, J. M. T., \& Gray, E. R. (1999). Corporate identities and corporate communications: Creating a competitive advantage. Corporate Communications: An International Journal, 4(4), 171-176. doi: 10.1108/00197850010379811

Bhatia, V. K. (1993). Analysing genre: Language use in professional settings. London: Longman.

Bhatia, V. K. (1996). Methodological issues in genre analysis. Hermes, 16, 39-59. doi: 10.7146/hjlcb.v9i16.25383

Bhatia, V. K. (2004). Worlds of written discourse. London/New York: Continuum.

Bhatia, V. K., \& Lung, J. (2006). Corporate identity and generic integrity in business discourse. In J. C. Palmer-Silveira, M. F. Ruiz-Garrido, \& I. Fortanet-Gómez (Eds.), Intercultural and international business communication: Theory, research and teaching (pp. 265-285). Bern: Peter Lang.

Bhatia, V. K., Flowerdew, J., \& Jones, R. H. (Eds.) (2008). Advances in discourse studies. London/New York: Routledge.

Bolaños Medina, A., Rodríguez Medina, M. J., Bolaños Medina, L., \& Losada García, L. (2005). Analysing digital genres: Function and functionality in corporate websites of computer hardware. Ibérica, 9, 123-147. Retrieved from http://www.redalyc.org/pdf/2870/287023983007.pdf

Bolter, J. D. (2001). Writing space. Hillsdale, NJ: Lawrence Erlbaum Associates. 
Bolter, J. D. (2016). Remediation. In R. T. Craig, K. B. Jensen, J. D. Pooley, \& E. W. Rothenbuhler (Eds.), The international encyclopedia of communication theory and philosophy (pp. 1-11). Hoboken, NJ: John Wiley \& Sons. doi: 10.1002/9781118766804.wbiect207

Bolter, J. D., \& Grusin, R. (1999). Remediation: Understanding new media. Cambridge, MA: MIT Press.

Breeze, R. (2013). Corporate discourse. London: Bloomsbury.

Catenaccio, P. (2012). A genre-theory approach to the website: Some preliminary considerations. In S. Campagna, G. Garzone, C. Ilie, \& E. Rowley-Jolivet (Eds.), Evolving genres in web-mediated communication (pp. 27-52). Bern: Peter Lang.

Cheng, W. (2011). 'Excellence, always': A genre analysis of engineering company brochures. In R. Salvi, \& H. Tanaka (Eds.), Intercultural interactions in business and management (pp. 45-72). Bern: Peter Lang.

Christensen, L. T., Fuat Firat, A., \& Cornelissen, J. (2009). New tensions and challenges in integrated communications. Corporate Communications: An International Journal, 14(2), 207-219. doi: 10.1108/13563280910953870

Crawford Camiciottoli, B., \& Bonsignori, V. (2015). The Pisa audiovisual corpus project: A multimodal approach to ESP research and teaching. ESP Today, 3(2), 139-159.

Dahlsrud, A. (2008). How corporate social responsibility is defined: An analysis of 37 definitions. Corporate Social Responsibility and Environmental Management, 15(1), 113. doi: $10.1002 /$ csr.132

Ellerup Nielsen, A. (2002). Rhetorical features of the company website. Aarhus: The Centre for Internet Research. Retrieved from http://cfi.au.dk/fileadmin/www.cfi.au.dk/publikationer/cfis_skriftserie/006_nielsen.pdf

Esrock, S. L., \& Leichty, G. B. (2000). Organization of corporate web pages: Publics and functions. Public Relations Review, 26(3), 327-344. doi: 10.1016/S03638111(00)00051-5

Garzone, G. (2007). Genres, multimodality and the World Wide Web: Theoretical issues. In G. Garzone, G. Poncini, \& P. Catenaccio (Eds.), Multimodality in corporate communication (pp. 15-30). Milan: Franco Angeli.

Garzone, G. (2009). Multimodal analysis. In F. Bargiela-Chiappini (Ed.), The handbook of business discourse (pp. 155-165). Edinburgh: Edinburgh University Press.

Gatti, L., \& Seele, P. (2014). Evidence for the prevalence of the sustainability concept in European corporate responsibility reporting. Sustainability Science, 9(1), 89-102. doi: 10.1007/s11625-013-0233-5

Gotti, M., Berkenkotter, C., \& Bhatia, V. K. (Eds.) (2012). Insights into academic genres. Bern: Peter Lang.

Heyd, T. (2016). Digital genres and processes of remediation. In A. Georgakopoulou, \& T. Spilioti (Eds.), The Routledge handbook of language and digital communication (pp. 87-102). London/New York: Routledge.

Iedema, R. (2003). Multimodality, resemiotization: Extending the analysis of discourse as multi-semiotic practice. Visual Communication, 2(1), 29-57. doi: $10.1177 / 1470357203002001751$

Jewitt, C. (2014). An introduction to multimodality. In C. Jewitt (Ed.), The Routledge handbook of multimodal analysis (2nd ed.) (pp. 14-27). London/New York: Routledge. 
Jewitt, C. (2016). Multimodal analysis. In A. Georgakopoulou, \& T. Spilioti (Eds.), The Routledge handbook of language and digital communication (pp. 69-84). London/New York: Routledge.

King, D. L., Case, C. J., \& Premo, K. M. (2010). Current mission statement emphasis: Be ethical and go global. Academy of Strategic Management Journal, 9(2), 73-89. Retrieved from http://www.abacademies.org/articles/asmjvol9no22010.pdf

Kotler, P. (1998). Principles of marketing. Harlow: Prentice Hall Europe.

Kress, G., \& Van Leeuwen, T. (2006). Reading images: The grammar of visual design (2nd ed.). London/New York: Routledge.

Landow, G. P. (2006). Hypertext 3.0: Critical theory and new media in an era of globalization. Baltimore/London: The John Hopkins University Press.

Lemke, J. L. (1998). Multiplying meaning: Visual and verbal semiotics in scientific text. In J. R. Martin, \& R. Veel (Eds.), Reading science: Critical and functional perspectives on discourse of science (pp. 87-113). London/New York: Routledge.

Lock, I., \& Seele, P. (2016). The credibility of CSR (corporate social responsibility) reports in Europe. Evidence from a quantitative content analysis in 11 countries. Journal of Cleaner Production, 122, 186-200. doi: 10.1016/j.jclepro.2016.02.060

Melewar T. C., \& Karaosmanoglu, E. (2006). Seven dimensions of corporate identity: A categorisation from the practitioners' perspectives. European Journal of Marketing, 40(7/8), 46-869. doi: 10.1108/03090560610670025

Nielsen, M. (2001). The company brochure as a genre: Towards a textogram based on Danish and German brewery brochures. Hermes, 27, 215-228. doi: 10.7146/hjlcb.v14i27.25657

Noguchi, J. (2003). Teaching ESP writing: OCHA in a CALL class. Cybermedia Forum, 4. Retrieved from http://www.cmc.osaka-u.ac.jp/publication/for-2003/40-45.html

O'Halloran, K. L. (Ed.) (2004). Multimodal discourse analysis. London/New York: Continuum.

O’Halloran, K. L. (2011). Multimodal discourse analysis. In K. Hyland, \& B. Paltridge (Eds.), The Continuum companion to discourse (pp. 120-137). London/New York: Continuum.

Perry, M., \& Bodkin, C. D. (2002). Fortune 500 manufacturer web sites. Innovative marketing strategies or cyberbrochures? Industrial Marketing Management, 31, 133144. doi: 10.1016/S0019-8501(01)00187-0

Pollach, I. (2005). Corporate self-presentation on the WWW. Strategies for enhancing usability, credibility and utility. Corporate Communications: An International Journal, 10(4), 285-301. doi: 10.1108/13563280510630098

Poppi, F. (2012). Global interactions in English as a lingua franca: How written communication is changing under the influence of electronic media and new contexts of use. Bern: Peter Lang.

Swales, J. M. (1990). Genre analysis. English in academic and research settings. Cambridge: Cambridge University Press.

Swales, J. M., \& Rogers, P. (1995). Discourse and the projection of corporate culture: The mission statement. Discourse \& Society, 6(2), 223-242. https://doi.org/10.1177/0957926595006002005 
Tang, L., Gallagher, C. C., \& Bie, B. (2015). Corporate social responsibility communication through corporate websites: A comparison of leading corporations in the United States and China. International Journal of Business Communication, 52(2), 205-227. doi: $10.1177 / 2329488414525443$

Topalian, A. (2003). Experienced reality: The development of corporate identity in the digital era. European Journal of Marketing, 37(7/8), 1119-1132. doi: $10.1108 / 03090560310477690$

Turnbull, J. (2011). How 'glocal' is corporate discourse? A case study of a multinational's website. In R. Salvi, \& H. Tanaka (Eds.), Intercultural interactions in business and management (pp. 73-90). Bern: Peter Lang.

Turnbull, J. (2013). Tracking the evolution of genres: The case of corporate websites. In F. Poppi, \& W. Cheng (Eds.), The three waves of globalization: Winds of change in professional, institutional and academic genres (pp. 37-55). Cambridge: Cambridge Scholars Publishing.

Van Riel, C. B. M., \& Fombrun, C. J. (2007). Essentials of corporate communication. London/New York: Routledge.

Yu, D., \& Bondi, M. (2017). The generic structure of CSR reports in Italian, Chinese, and English: A corpus-based analysis. IEEE Transactions on Professional Communication, 60, 273-291. doi: 10.1109/TPC.2017.2702040

Zhang, Z. (2007). Towards and integrated approach to teaching Business English: A Chinese experience. English for Specific Purposes, 26, 399-410. https://doi.org/10.1016/j.esp.2006.10.006

EMANUELA TENCA received her PhD at the University of Modena and Reggio Emilia (Italy). Her research interests include international and intercultural business communication, web-mediated corporate communication, English as a business lingua franca, English for specific purposes, and multimodal discourse analysis. Currently, she is adjunct professor of English at the University of Padua (Italy).

\section{Appendix}

Overview of the corpus

\begin{tabular}{|l|l|l|}
\hline COMPANY NAME & CoUNTRY OF ORIGIN & URL \\
\hline Acciona Energía Solar SL & Spain & http://www.acciona-energia.com/ \\
\hline A. Silva Matos Energia SA & Portugal & http://www.asilvamatos.pt/\#/en/ \\
\hline Avanti Wind Systems AS & Denmark & http://www.avanti-online.com/en/ \\
\hline Bonfiglioli Riduttori SpA & Italy & http://www.bonfiglioli.com/en/ \\
\hline CHO-Power - Europlasma Group & France & http://www.cho-power.com/ \\
\hline Cryostar SAS & France & http://www.cryostar.com/ \\
\hline Deep Drill Supply Group & The Netherlands & http://www.deepdrill.nl/ \\
\hline dnpSolar & Denmark & http://www.dnpsolar.eu/ \\
\hline EnBW AG & Germany & https://www.enbw.com/index_en.html \\
\hline enso hydro GmbH & Austria & http://www.enso.at/en/home/ \\
\hline Fröling GmbH & Austria & http://www.froeling.com/ww/ \\
\hline GA Drilling as & Slovakia & http://www.gadrilling.com/ \\
\hline
\end{tabular}




\begin{tabular}{|l|l|l|}
\hline Geotermica AB & Sweden & http://www.geotermica.se/index_eng.html \\
\hline GOLIATH Wind OÜ & Estonia & http://www.goliath.ee/ \\
\hline ib vogt GmbH & Germany & www.ibvogt.com \\
\hline IREM SpA & Italy & http://www.irem.it/ENG/index.php \\
\hline L MAG Rare-Earth Co. Europe b.v. & The Netherlands & http://www.a-m-g.com/English-1-t.html \\
\hline uwi AG & Germany & http://www.juwi.com/homepage.html \\
\hline Luvata Pori Oy & Finland & http://www.luvata.com/ \\
\hline Mabanaft GmbH & Germany & http://www.mabanaft.de/Mabanaft/en/home/index.php \\
\hline Mervento Oy & Finland & http://www.mervento.com/In\%20English/HOME/Default.aspx \\
\hline Micron - Cappello Alluminio srl & Italy & http://www.micronsun.it/2275?lang=EN\#.VJl_9l4AJ \\
\hline Palazzetti SpA & Italy & http://www.palazzettigroup.com/en/ \\
\hline PCC SE & Germany & http://www.pcc.eu/ttw/pcc.nsf/id/EN_Home \\
\hline Profish Technology SA & Belgium & http://www.profish-technology.be/en/ \\
\hline Silcio SA & Greece & http://www.silcio.gr/en/index.html \\
\hline Smart Hydro Power GmbH & Germany & http://www.smart-hydro.de/en/home.html \\
\hline Sveaskog Förvaltning AB & Sweden & http://www.sveaskog.se/en/ \\
\hline Turboden srl & Italy & http://www.turboden.eu/en/home/index.php \\
\hline Vapo Oy & Finland & http://www.vapo.fi/en \\
\hline
\end{tabular}

